\title{
私の診療とエ夫 I
}

\section{腹腔鏡赤外光観察システムを用いた ICG による 大腸癌センチネルリンパ節同定とその手技の工夫}

\author{
永田 浩一 遠藤 俊吾 日高 英二 吉田 達也 出口 義雄 \\ 辰川貴志子石田 文生 田中 淳一 工藤 進英 \\ 昭和大学横浜市北部病院消化器センター
}

索引用語：infrared ray, sentinel node navigation, colon cancer

はじめに

消化器癌に対する系統的リンパ節郭清の確立は, 治療成績の向上に寄与してきた。一方，低侵襲，か つ機能温存を目的として, 腹腔鏡補助下での大腸癌 手術が急速に広まりつつある。この腹腔鏡手術に， より合理的なリンパ節郭清を組み合わせることで, 真の低侵襲手術となりえると考えられる.この際に, sentinel node navigation はリンパ節郭清範囲を縮小 する上で有力な手段になる可能性がある．現在のセ ンチネルリンパ節 (以下，SN) 検出には radioisotope 法 (以下, RI) と色素法が行われている. RI 法は術 前診断が可能で，定量的同定や見落としが少ないと いう長所がある。しかし，放射性元素を扱うため， 特殊な設備や放射線安全管理が必要となる点が短所 である．また，この方法では，注入部位から出る放 射状のアーチファクトで壁在リンパ節が隠ペいされ たり，注入部位とリンパ節が重なることがあり (shine through 現象)，これらの現象を防ぐために 様々な工夫が必要となる。 それに対して，色素法は $\mathrm{SN}$ を術中に視覚化できることや，放射線被曝がな い点が優れている. しかし, 色素自体の色を直視下 で確認するため，色素の入ったリンパ節の染まりが 薄ければ，見にくいという欠点がある．また，腹腔 鏡下では，薄い腸壁への色素注入が難しいことや，

A New Technology of Sentinel Node Navigation using Infrared Ray during Laparoscopy-assisted Surgery for Colorectal Cancer Digestive Disease Center, Showa University Northern Yokohama Hospital

K. Nagata, S. Endo, E. Hidaka, T. Yoshida, Y. Deguchi, K Tatsukawa, F. Ishida, J. Tanaka and S. Kudo

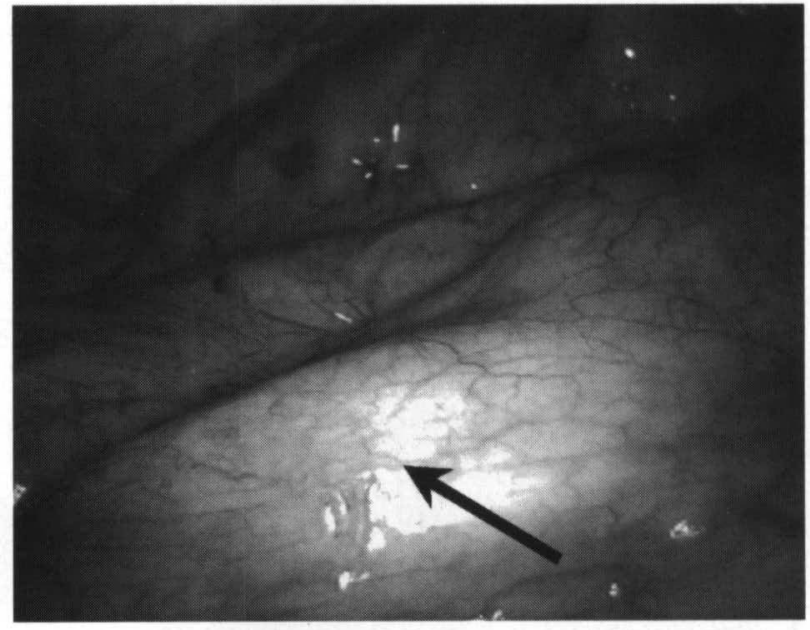

図 1 通常光観察 色素が透見されないためリンパ節, リンパ管の観察は不可能（矢 印).

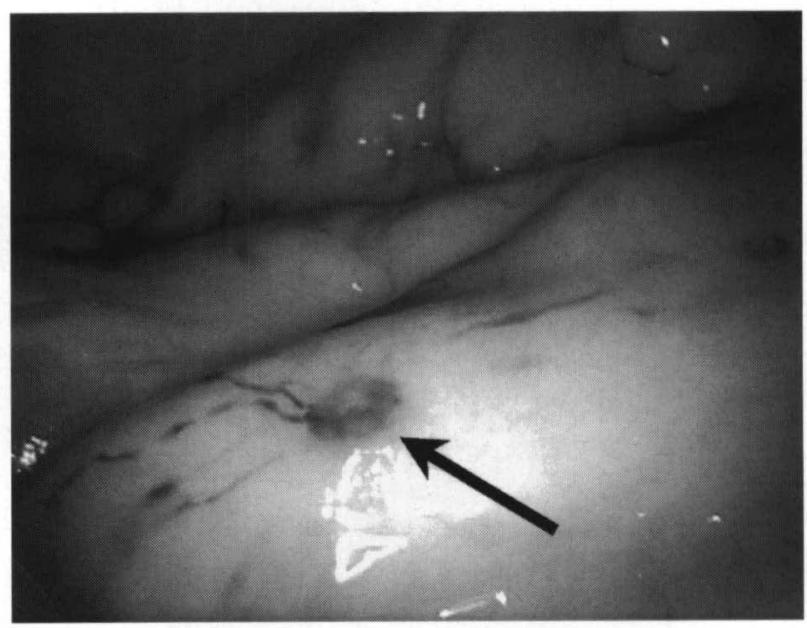

図 2 赤外光観察

リンパ管とそれに続いた SN（252 番リンパ節）が明暸に観察され た (矢印). 
術中の内視鏡下色素注入は右側結腸病変では煩雑で あるなどの手技上の問題がある。 そのため，色素法 は開腹手術で行われることが多く，本来ナビゲー ションサージェリーが有効となる腹腔鏡下手術では 十分な観察が難しい.今回, 腹腔鏡下大腸手術での 腸管壁への色素の注入法として，生食注入併用点墨 法" ${ }^{12}$ 応用した生食注入併用色素法を考案した.そし て通常光での観察のほかに, 腹腔鏡赤外光観察シス テム (Olympus 社製) も用いて，大腸癌の SN 同定 の簡便性を検討した2).

\section{対象および方法}

対象は腹膜翻転部より口側の大腸癌症例である. 色素注入 5 分後から約 10 分間かけて腹腔鏡通常光 下と赤外光下に観察し，SN を判定した。色素は indocyanine green (以下, ICG) $25 \mathrm{mg}$ 蒸留水 $5 \mathrm{ml}$ に溶解したものを使用した。その手順を述べると， 術前に行った大腸内視鏡の際に病変近傍においた マーキングクリップを，術中透視により確認する.

腹腔鏡下に病変を中心として腸管を腹側に挙上す

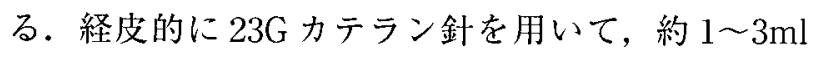
の生理食塩水を漿膜下に注入する。この際に生食水 が壁内に注入されていることを，注入抵抗，漿膜側 の膨隆から確認する.その後, この針を抜かずに, ICG 溶解液 $2.5 \mathrm{ml}$ を注入する.これを病変の口側と 肛門側の 2 力所に行う. ICG は近赤外線光 $(805 \mathrm{~nm}$ 付近）に吸収ピークがあるため, 赤外線スコープで 近赤外線光を照射すると, ICG が注入されたリンパ 管, リンパ節は黒く強調して観察される.

\section{結果および考察}

腹腔鏡下で通常光観察と赤外光観察を併用したと ころ, 通常光での観察は薄く染まった SN の観察が 困難であった。とくに，脂肪が豊富な腸間膜におい ては，通常光観察では色素の透見が制限された（図 1). それに対して, 赤外光観察では SN 同定が容易と なり，有用であった（図 2)。しかしながら，赤外線 スコープによるSNの観察は非常に鮮明に描出でき るために,色素注入の際に色素をこぼしてしまうと， 観察範囲内が全て黒染して観察されるため検査不能 となることがあった．このような，失敗を起こさな いように術者によらず簡便に検查を施行するため に，遠藤らの報告にある大腸内視鏡検查における生 食注入併用点墨法を本法に応用した”。大腸癌に対 する色素法によるSNの観察は開腹手術あるいは Hand-assisted laparoscopic surgery で行うか, 術中 に大腸内視鏡を行う必要があった。しかし，この方 法を用いることで, 従来と異なり体外から, 腹腔内 にこぼすことなく，確実に色素を腫場近傍に注入す ることが可能となり，腹腔鏡手術への応用が容易と なった.

本稿を終えるにあたり，御助言をいただきました昭和大学 横浜市北部病院消化器センター井上晴洋助教授に深く感謝 の意を表します。

\section{文献}

1）遠藤俊吾, 加藤博之, 吉松和彦ほか：腹腔鏡補助下大腸 切除術における病変部位同定のための点墨の工夫. 日本 大腸肍門病会誌 $52: 372-373,1999$

2）二村浩史, 樫村弘隆, 佐野芳史ほか：赤外線内視鏡を用 いたICGによる sentinel node navigation. 日消外会誌 $34: 520,2001$

(2003 年 5 月 8 日受付) (2003 年6月 18 日受理) 